\title{
The Case that Felled a City: Examining the Politics of Indian Public Interest Litigation through One
} Case

\section{Anuj Bhuwania}

\section{(2) OpenEdition}

\section{Journals}

Electronic version

URL: http://journals.openedition.org/samaj/4469

DOI: $10.4000 /$ samaj.4469

ISSN: 1960-6060

Publisher

Association pour la recherche sur l'Asie du Sud (ARAS)

Electronic reference

Anuj Bhuwania, «The Case that Felled a City: Examining the Politics of Indian Public Interest Litigation through One Case », South Asia Multidisciplinary Academic Journal [Online], 17| 2018, Online since 13 February 2018, connection on 30 April 2019. URL : http://journals.openedition.org/samaj/4469 ; DOI 10.4000/samaj.4469

This text was automatically generated on 30 April 2019.

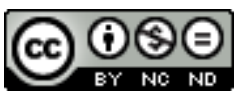

This work is licensed under a Creative Commons Attribution-NonCommercial-NoDerivatives 4.0 International License. 


\title{
The Case that Felled a City: Examining the Politics of Indian Public Interest Litigation through One Case
}

\author{
Anuj Bhuwania
}

"The new role of the Supreme Court is that of a policymaker, lawmaker, public educator and super administrator all rolled in one. In the US, they have the Congress, the Federal Environment Protection Agency and bags of money to protect the natural environment. Here, we have our Supreme Court" (Divan 1995).

“In Delhi, in 2000, so much of the government's activity in so many matters boiled down to securing compliance of Court orders in PIL that one might have been excused for thinking of it as the Court's bailiff" (Verma 2002:88).

1 In 1984-85 a lawyer named MC Mehta filed a bunch of Public Interest Litigation (PIL) cases in the Supreme Court of India. These cases were fated to be landmarks in the history of PIL in India and are generally discussed as the archetypical environmental PILs, which set the pace of judicial intervention in urban governance and environmental regulation in India. In narrating the story of PIL, these cases are usually read as signaling a new era, shifting the focus of PIL away from what had been its dominant concerns until then-poverty and judicial reform-to the subject of the environment. These cases have been trailblazers in exploring the boundless potentialities of PIL in India, particularly in Delhi. My focus in this article, however, will be on the pioneering innovations introduced in these PIL cases. I will foreground these fundamental procedural departures and the politics immanent in them. 
2 PIL was primarily a revolution in judicial procedure, and while this fact is noted, it is often glossed over in the study of its functioning. India's PIL jurisdiction is generally acknowledged to have a fair amount of procedural flexibility, but it is still studied as if a PIL is like any other case in terms of its materiality. For instance, in legal academic analyses of PIL, attention continues to be focused on the analysis of the completed judgment although many such cases never actually end at all, but comprise an agglomeration of orders or judgments issued over time. The emphasis on the dilution of locus standi of the petitioner as the only major unconventional attribute of a PIL case represses the other radical characteristics of such cases that in reality take it far beyond any understanding of an adjudicative proceeding. I would argue here that traditional modes of studying judicial behavior do not really suffice for PIL cases, some of which never even culminate in final judgments.

3 Four of these MC Mehta PILs from 1984-85 are still in progress after three decades, with no end in sight. The unending nature of these cases provides us with a hint as to their unique nature. These four vintage, yet still thriving PILs are the cases popularly known as the Taj Mahal Pollution case, ${ }^{1}$ the Ganga Pollution case, ${ }^{2}$ the Delhi Vehicular Pollution case $^{3}$ and the particular case that I will be focusing on here, Writ Petition (Civil) 4677/1985. No such simple moniker would work for the latter case as its very cause of action, i.e. its central dispute shifted, not once, but multiple times in the last three decades. It started with a plea against stone-crushing units, then concerned itself with pollution in the river Yamuna, then with the condition of the Ridge Forest and with mining in the Aravalli mountain ranges, but its most famous targets were hazardous large industries, then "non-confirming" industries and finally and most spectacularly it became known as the "sealing" case against commercial establishments in residential areas. The story of this PIL case can be narrated as the story of Delhi's urban transformation in the last three decades as it singlehandedly led to large-scale deindustrialization of the city. This PIL did perform this task assiduously and relentlessly. But the question that is worth posing here is: why and how did PIL emerge as the primary agent of this transformation. While Delhi, just like many other cities, saw massive changes in its political economy during this period with a move from industry to services, what marks Delhi's dislocations as distinct is their source and their basis-they are based not, as in the past, on administrative or municipal policy or executive directives, but on judicial directives in a single PIL case concerning pollution in the city. The spectacular efficacy of a PIL case in carrying out such a role, I would argue, can be explained not just by the external ideological trends prevailing at the time, but also by the peculiar nature of PIL itself. While WP 4677/1985 became a means of spectacular urban transformation, it also broke fresh ground for PIL itself as a perennially unstable and fundamentally malleable jurisdiction. The shifts that these cases brought about in PIL affected not only its political economy, but also the very nature of its process. This is the story I shall try to narrate here.

WP 4677/1985 has been dealt with by most of the leading charismatic PIL judges of the last three decades from Justice Bhagwati to Justice Kuldip Singh and Justice Sabharwal, making it particularly fertile as a case study for the history of PIL. While the focus of this article will be on this one case, I will begin with a brief discussion of another of the still surviving MC Mehta cases of 1985, the vehicular pollution case, in so far as it resonates with the particular case at hand. While the MC Mehta cases were first admitted by Justice Bhagwati in 1985, these cases scaled new heights in the early 1990s with Justice Kuldip 
Singh at the helm, enabling him to establish a reputation as a "green judge." The style of functioning of his Court at this time can be discerned from the following description provided in 1995 by Shyam Divan, then a young environmental lawyer:

A public interest litigation to clean up the Ganga has caught the judge's fancy. Each Friday a huge shoal of advocates, administrators, company executives, and public officials attentively follow the Court proceedings as a range of snappy judicial directions are issued... The Ganga Court functions a bit like a village panchayat dispensing justice in the shade of a banyan tree. The rigor of formal Court procedures and statutory requirements are diluted in favor of a summary, resultoriented process (Divan 1995:1557).

To characterize so peculiar an attempt to mimic "traditional justice" in the hallowed portals of India's Supreme Court with its liveried attendants in turbans and full Raj-style regalia, perhaps a more appropriate analogy would be the medieval Court or durbar rather than a village panchayat. Justice Hidayatullah had anticipated this and as early as 1984, he thought it fit to compare PIL with Moghul Emperor Jehangir's "Zanjir-e-Adl-a gold chain which he had hung from his apartment to the ground. Supplicants used to give a tug to ring a bell in his private apartment and the emperor would before a jharoka (window) and hear and decide the complaint in person" (Hidayatullah ${ }^{1984: 2) . ~ S u c h ~ j u d i c i a l ~}$ conduct as Divan observed above showed PIL as a jurisdiction where the highest Court of a common law judiciary was self-consciously trying to enact the Weberian ideal type of kadijustiz: "the administration of justice which is oriented not at fixed rules of a formally rational law but at the ethical, religious, political, or otherwise expediential postulates of a substantively rational law" (Rheinstein 1954:213). ${ }^{4}$ While J. Kuldip Singh's judicial conduct set new standards for PIL judges, it was not fated to be exceptional for too long, as we shall see.

\section{The Delhi Vehicular Pollution case}

5 Writ Petition (Civil) 13029/1985, better known as the Delhi vehicular pollution case, was to lead to a complete overhaul of public and private transport in the city. Its impact started to be felt with a series of orders in the mid-1990s. Its initial orders included the phasing-out of leaded gasoline, the introduction of pre-mixed fuels for two-stroke engine vehicles and the removal of 15-year-old commercial vehicles. But soon-to-come in this case was the most famous of its decisions-to order all commercial public transport vehicles to change from diesel or petrol to Compressed Natural Gas (CNG), which was seen as a "green" fuel. The decisions were actually taken at the behest of a fact-finding body called the Environment Pollution (Prevention and Control) Authority, abbreviated as EPCA and commonly referred to as the Bhure Lal Committee after its chairman, who was then a member of the Central Vigilance Commission. The EPCA was appointed as a statutory body on January 28, 1998 under the orders of the Court. This five-member committee was initially composed of a representative from the Central Pollution Control Board, the Automobile Manufacturers Association of India, the Centre for Science and Environment (an environmental NGO) and the Transport Department of Delhi, in addition to the Chairman..$^{5}$ Because the committee was designed to speak to the interests and expertise of the major affected parties, since 1998, the Supreme Court has consistently looked to the committee as its fact-finding commission and has relied almost exclusively on its findings when making its decisions in this Case (Rosencranz and Jackson 2003:15). of course the Court has not always followed EPCA recommendations-the most 
prominent example of such an instance being the fate of diesel-fueled private vehicles. As a 2004 article on this case notes,

The Environment Pollution (Prevention and Control) Authority (EPCA) recommended that private diesel cars should not be registered and that the Supreme Court should freeze sales of diesel cars. Lawyers for the automobile industry strenuously opposed this. Instead of following the EPCA recommendation, the Court ordered only that all private cars must conform to engine standards by new, tighter deadlines (Bell et al. 2004:39; see also Mathur 2003).

Another glaring instance of the Court's skewed sense of priorities in this case was when it did follow EPCA recommendations and directed (on the same day as the CNG order) to augment the number of public transport buses in Delhi up to 10,000 by April 1, 2001. ${ }^{6}$ But the Court did not make any significant effort to implement this order (while its other orders were wreaking havoc) and even in 2015, Delhi has much less than 10,000 public buses in its fleet.

The petitioner MC Mehta was active in the Delhi vehicular pollution case up until 1995. Thereafter the Court relied on Harish Salve, a senior lawyer who was appointed as the amicus curiae-literally "friend of the Court," a Court-designated position that became increasingly common in PIL cases around this period. The crucial role that the amicus played here has been described thus: "In this case, the amicus curiae was a combination of special master and advisor to the justices" (Bell et al. 2004:39). He collected and sorted out factual material and distilled from the numerous affidavits and other representations submitted to the Court a précis of their perspectives. At several critical junctures, Salve did factual research to debunk what he described as "extravagant claims" and otherwise played a central role in moving the case forward (Bell et al. 2004:39). For a case of citywide scope, a relatively small number of stakeholders actually played much of a part in the deliberations.

On July 28,1998 , the Supreme Court issued its order that all public transport in Delhi would be converted to run on CNG by April 1, 2001. ${ }^{7}$ The CNG order included buses, taxis and auto-rickshaws, some 100,000 vehicles in all (Trust N.d.:12). This was immensely controversial because the science behind it was severely contested, with two committees giving diametrically opposite reports regarding the advisability of adopting diesel or CNG (Sharan 2005; Rosencranz and Jackson 2003:223). Even if the problem of pollution in Delhi was widely acknowledged to be severe, many alternative solutions to this dismal situation had been suggested. The most controversial aspect of the Court's solution was that private vehicles were relatively unaffected, while public transport was made to bear the brunt-directly affecting the livelihoods of people employed in public transport. The effect of this forced change of fuel on bus personnel and commuters was drastic. There was a sudden drop in the number of public buses available.

The drivers of auto-rickshaws (officially known as TSRs: "Three-wheeled scooter rickshaws") were particularly badly hit. The changeover from petrol to CNG engines required a relatively large monetary investment, which most auto-rickshaw drivers were not in position to make, and bank loans were hardly available to them. They ended up taking usurious loans from private financiers. Besides, CNG was not actually available in sufficient quantity for many years, even after it had been imposed as the only fuel for auto-rickshaws. This led to extreme hardship, as auto-rickshaw drivers would normally have to queue for 3-4 hours to refuel their vehicles, which affected their workdays very adversely. Serpentine queues of dozens of auto-rickshaws outside gas stations were to become a normal sight in Delhi in the first few years of the $21^{\text {st }}$ century. 
The auto-rickshaw drivers' situation was actually exacerbated by an earlier order of the Supreme Court in this same case in 1997, which stated that:

It would be in the interest of the environment, to freeze the number of TSRs for the present at the level at which they are actually in use in the city. We, therefore, direct that there would be no grant of fresh permits in respect of the TSR, save and except by way of replacement of an existing working TSR with a new one. ${ }^{8}$

The result of this court-ordered permit-freeze was catastrophic for auto-rickshaw drivers. In 2010, the EPCA found that, according to the Transport Department of the Government of Delhi, the number of registered three-wheelers in the city was 55,236, while 72,429 of them had existed in 1997 (EPCA 2010). There was thus a substantial decline in absolute numbers of auto-rickshaws in Delhi between 1997 and 2010. Simultaneously, by 2010, as the EPCA observed, the city was registering over 1,000 new private vehicles every day. Thus, in the period from 1997 to 2011, while private vehicles increased exponentially, the Supreme Court's freeze on TSRs resulted in an artificial scarcity of permits.

The decline in the number of auto-rickshaws in Delhi's streets was due to the combined effect of the Supreme Court's TSR-freeze order of 1997 and its enforcement of CNG conversion soon after. In 2002, the Court did allow a minuscule 5,000 new permits to be issued, but otherwise the number of TSRs remained stagnant until 2011, when the Court finally allowed 45,000 new permits after the TSR unions approached it in August 2009, and appealed for relief from the freeze "in view of the increase in population and increase in the number of vehicles during the past several years." The Court asked the EPCA to examine the matter afresh and requested it "to give a report as regards the needfulness for fresh permissions for three wheelers." 9

The situation that then prevailed was explained in a 2010 report on auto-rickshaws in Delhi:

The permit cap created a gap between the supply of autos and the growing demand from Delhi's increasing population. A black market for auto permits soon emerged and the price of an auto permit rose dramatically. Just a year later owner-drivers were ordered to replace their autos or convert them to $\mathrm{CNG}$ by fitting expensive conversion kits. Unable to afford the Rs. 25-30,000 CNG kits, thousands of owner drivers had no option but to sell their autos and permits to financiers at bargain prices, further focusing power in the hands of the consolidating finance "mafia" (Trust N.d.:2).

The black market price of an auto-rickshaw with permit increased to 6.5 lakh rupees by 2011, while the cost of the auto-rickshaw itself was only 1.4 lakhs-a difference of more than 5 lakhs (Harding 2011). In November 2011 when the Supreme Court finally allowed 45,000 new auto-rickshaw licenses to be granted, the market price immediately crashed and went down to as low as 2.5 lakh rupees. ${ }^{10}$ The creation of this black market in TSRs was purely a result of the Supreme Court's decision, as can be gauged from the results of its revocation. Already, the order about change in fuel had made many auto-rickshaw owners take loans from private financiers, and when they were unable to pay these back, they had to transfer their permits to these financiers. Studies have shown that before the Supreme Court's double whammy, most auto-rickshaws were owned by drivers themselves, while the effect of the fuel change and the permit freeze was that almost the entire fleet of auto-rickshaws came under the control of financiers, and drivers were converted into wage labor. ${ }^{11}$ Even the EPCA recognized in 2010 that "the bulk of the vehicles on road are owned by a limited number of people who rent these to drivers on a charge of around Rs 250-300 for an 8-hour shift." By the time the EPCA recommended 
Nyaya Bhoomi v. Transport Department (2011), the removal of the cap on auto-rickshaws, recognizing their importance as public transportation and finally understanding the impact of the Court-ordered freeze, great harm had been done to all concerned. As its 2010 report noted:

EPCA has noted that the current crisis of pollution in the city and its adjoining areas is largely because of the exponential growth of private vehicles. The only option for the city in the future is to provide a viable and reliable public transport system, which will restrain the use of private vehicles on the roads. The threewheeler plays an important role in providing an intermediate public transport facility. It remains cheaper to operate as compared to any four-wheeled vehicle and removal of the cap and the high transaction costs associated with it will bring down the cost of capital drastically and provide space for improvement of the service on road. Removal of cap will also help in eliminating the dominating hold of "financier's mafia" who are exploiting not only the drivers but also general public by pushing up artificially the capital cost of 3-wheelers and hence the operational cost (EPCA 2010).

Both these decisions-the permit freeze and the CNG changeover-in the Delhi Pollution case were taken without even giving the city's auto-rickshaw drivers and their representatives a chance to argue their side of the story. I was witness in August 2009 to the proceedings of this case. An application had been filed in the Supreme Court for its permission to increase the number, which had been set in 2002, of permits for autorickshaws. The lawyer for the auto-rickshaw union had just begun his oral submission pleading for notice to be issued in this case, because seven years had passed since the freeze, and the rationale for the original order of 1997-that auto-rickshaws were polluting vehicles-was now irrelevant since the CNG fuel now used was eco-friendly. If notice had been issued, the application would in any case have been examined by the EPCA, and based on their recommendation, the Court would have considered granting permission. But the amicus curiae Harish Salve weighed in, opposing the application itself. His contention was that the presence of auto-rickshaws on Delhi roads led to traffic congestion, because of which motor vehicles generally had to spend more time in stationary mode with engines on, leading to further pollution, therefore even CNG-fuelled auto-rickshaws would cause pollution. Presumably, in Salve's reasoning the introduction of thousands of motor vehicles in the city on a daily basis would cause no such problem. No authorities were cited by Salve and this was an extempore objection by him.

In this case which transformed Delhi's roads, the Supreme Court displayed a stark preference for imposing disproportionate environmental costs on public transport while allowing private transport to thrive, even though the latter was the cause of most of the vehicular pollution in Delhi. The case induced a marked increase in private transport, which had expanded so exponentially since the Court's actions of the late 1990s that the reduction in carbon emissions of public transport vehicle was over the period more than compensated for by the rise of private vehicles, particularly diesel vehicles.

13 An ideological interpretation of this case can rightly be made, as it significantly worsened the livelihood of thousands of poor informal-sector transport workers in the name of environmental problems and the need for clean fuel, while stimulating the demand and supply of private automobiles, just when this sector was opening up in a postliberalization Indian economy. While such an interpretation would not be incorrect, I would instead ask a different question: why was the Court the instrument of such a major policy change? And how was this forced transition carried out? 

spectra of vehicular pollution without adequately considering the impact its interventions would have on vulnerable sections of the population who live a hand-tomouth existence, and without making any effort to cushion them from the harsh economic effects of such a transition. There was a callousness at work in which a blinkered and absolutist idea of environmentalism-Amita Baviskar called it "bourgeois environmentalism" (Baviskar 2002)-was imposed, where the poor are bizarrely and conveniently seen as responsible for urban pollution, and have to bear disproportionately the costs of moving to a more ecologically benign system. While Baviskar's diagnosis of such a trend is persuasive and spot on, it is worth reflecting on why PIL emerged as the most powerful weapon for this "bourgeois environmentalism" phenomenon. While a class-based ideologically inflected worldview among appellate judges is hardly new and indeed is part and parcel of any realist understanding of judicial behavior, PIL empowers judges to take their predilections much further than ordinary adjudication. It is the ability to enact and materialize a particular worldview that makes PIL so especially effective. I would argue that PIL was uniquely suited to impose such a worldview, not just because many judges shared it, but also because the extreme malleability of PIL empowered them to carry it out. In fact, the repeated exclusion of adversely affected parties from even getting a hearing that we see throughout the history of these "environmental" PIL cases is symptomatic of the fact that the class-based exclusions of "bourgeois environmentalism" gets materially inscribed within the adjudicatory processes of PIL.

Soon after this imposed fuel change, there was an appreciable drop in vehicular pollution in Delhi. The effects seemed to last for about a decade, after which the problem resurfaced, as the number of private vehicles had increased so much in the meantime that their combined emissions neutralized the reduced pollution caused by public transport. But the interesting thing about this case is not the ideological aspect as much as the Supreme Court's capacity to ride roughshod over the interests of tens of thousands of people employed in "non-corporate capital" (Chatterjee 2013:208-35), with the unspoken assumption that they could be made redundant and their concerns ignored. This kind of blinkered obliviousness is simply not conceivable by any democratic regime in India. The only time the Indian state could carry out such a draconian measure was perhaps during the Emergency regime. And therein you have the unique power of the Court, which as many critics have argued ${ }^{12}$ plays a very careful negotiating role when it comes to high politics, but as we have seen here, can take an intransigent stand when it comes to vulnerable groups. It is not irrelevant that many of these decisions were made during the period of 1998-2004, when Jagmohan, the principal architect of the Emergency era "cleaning up" of Delhi as the then Vice-Chairman of the Delhi Development Authority, held office in the NDA government at the Centre, as we will see in the next section.

WP(C) 13029/1985 continues to thrive with the same amicus curiae Mr. Harish Salve, who has held this position in this PIL for 2 decades now. This means, he is much more conversant with this case than any judge who hears it, because typically a Supreme Court judge officiates in such a case for 2-3 years at most. In the other unending mammoth PIL popularly known as "the forest case," in which Salve has served as amicus for a similar period, I have had a chance to witness him address and brief a new incumbent judge joining "the Forest Bench," so that the latter would also be acquainted with the background and "glorious" history of the case. ${ }^{13}$ The story of many landmark PIL cases is 
often written, with good reason, in terms of the judges heading the bench and is identified with their charisma, Justice Kuldip Singh being a good example. But perhaps the time has come to narrate the history of some other more recent PILs in terms of the charismatic amicus curiae involved in them, as they play a no less crucial role in steering the case in new directions. During its hearings in 2014-15, the veteran amicus in WP(C) 13029/85 was assisting the Court in supervising the construction of two big road projects -the Western and Peripheral Expressway, which would reroute vehicular traffic away from Delhi and thus reduce traffic and pollution in the city.

\section{WP(C) 4677/1985: The many-headed hydra}

One of the other still active PIL cases (Writ Petition (Civil) Number 4677) filed by MC Mehta in 1985 changed the face of Delhi more than any other case. It is generally regarded as a case concerning industrial pollution in Delhi as it famously led to the removal of industries from the city, in the name of implementing city-zoning laws, ${ }^{14}$ but this was just one of the many achievements of this PIL. The Master Plan of Delhi would get so much attention as a result of this case that it became a paperback bestseller during the mid-2000s. But WP(C) 4677/1985 initially started with a plea against stone-crushing units, which were alleged to be causing dust pollution in the city. 300 such units were closed down under Court orders in 1992 (Frontline 2000). Already, in a sign of things to come, after discussing the chaos in implementing these closure orders, leading legal commentators observed, "one may wonder whether the Supreme Court of India can have the time and resources for the above sort of micro-management" (Divan and Rosencranz 2002:259). No lessons were learnt from this experience however. Such chaos was repeated cyclically multiple times in the future avatars of this case and in ever-increasing scale, as we shall see. The PIL case did not come to a close with the achievement of the objective with which it was first filed. The continuation of the case, after the decree to close down the stone crushing units was passed, was not merely to monitor the implementation of its judgment, but to take up fresh causes of action. The closure of the units, in retrospect, was merely an unmarked blip in the juggernaut that this case became.

The petitioner MC Mehta thereafter filed a number of interlocutory applications (IAs) in this same case, relating to other aspects of pollution in Delhi. The initial ones related to pollution in the river Yamuna and led to the setting up of sewage treatment plants and common effluent treatment plants (Frontline 2002). Another big area of intervention in this case was the ridge forest of Delhi, which the Court wanted to protect in its "pristine glory." On May 9, 1996 the Court directed that the ridge be made free of all "encroachers," as per the terms of the Delhi Master Plan. This would impact over 30,000 residents living in three colonies adjacent to the Asola Wildlife Sanctuary. The affected residents were nomadic tribals, who used to work in the erstwhile Bhatti mines of this area. As Ravi Agarwal notes, "under direction from the Supreme Court they were asked to relocate, even though many adjoining private farmhouses were left untouched" (Agarwal 2010). Some of the tribal residents managed to resist eviction through political negotiations, but their fate remains precarious.

Another application, IA No. 29, relating to mining operations near Badkal Lake and Surajkund tourist resorts in the state of Haryana near Delhi, was filed as part of this PIL by the petitioner. The Court barred any mining activity within two kilometers of these resorts by an order dated May 10, 1996 (see Ahuja 1997:807). A spin-off of these IAs was 
the Court's intervention in curtailing mining in the Aravalli hills, a matter that this case continues to grapple with even after nearly two decades. The nature of the orders passed in this PIL under each of these headings was such that, even after the Court definitively pronounced on any of these issues, the implications of each were so broad and implementation so complicated with so many affected parties who were often not even represented, that each of them took years of the Supreme Court's time and some are still ongoing. As the case became larger and larger, the numbering of the numerous IAs filed by various parties in the various branches of this case became more and more unwieldy. As early as November 11, 2002, the order sheet of a hearing in this case lists an item it was dealing with as IA No. $1782 / 2001$, in IA No. 1172 , in IA No. 22 , in Writ Petition (Civil) No. $4677 / 1985 .{ }^{15}$ This one writ petition had so many heads, that it really was like a manyheaded hydra. Conventional modes of legal analysis would struggle to make sense of a juridical beast such as this writ.

With Justice Kuldip Singh at the helm in the 1990s, this case almost single-handedly led to the deindustrialization of Delhi (before Justice YK Sabharwal led it in a slightly different direction beginning in 2005). The first significant step in this direction culminated on July 8, 1996 with the Court ordering the relocation of 168 large industries outside of Delhi within five months. The Court reasoned:

Delhi is recording heavy population growth since 1951. As the city grows, its problems of land, housing, transportation and management of essential infrastructure like water supply and sewage have become more acute. Delhi is one of the most polluted cities in the world. The quality of ambient air is so hazardous that lung and respiratory diseases are on the increase. The city has become a vast and unmanageable conglomeration of commercial, industrial, unauthorised colonies, resettlement colonies and unplanned housing. There is total lack of open spaces and green areas. Once beautiful city, Delhi now presents a chaotic picture. The only way to relieve the capital city from the huge additional burden and pressures, is to deconcentrate the population, industries and economic activities in the city and relocate the same in various priority towns in the NCR. ${ }^{16}$

The Court's order was as per the "Second Master Plan for Delhi - Perspective 2001" (henceforth, the Master Plan) notified in 1990 which specifically provided that hazardous / noxious / heavy / large industries were not permitted to operate within the city of Delhi and the existing industrial units falling within these categories were to be shifted / relocated outside city limits. These industries were either characterized in the Delhi Master Plan's Annexure III as "H(a) category" meaning "Hazardous and noxious industries" or " $\mathrm{H}(\mathrm{b})$ category" meaning "heavy and large industries."

The Court ordered that if the factory owners chose to relocate to a neighboring district, they would have to pay each worker monthly wages during the period of the move, as well as one year's salary as a resettlement bonus. If owners opted to close their factories, workers would be entitled to six years' wages as a retrenchment allowance. Two years later, it was found that only one out of the 168 industries had paid any compensation to the workers (Dasgupta 1998). In any case, the liability of the factory management was limited to the narrowest possible definition of "workmen," those who were on the rolls as permanent employees (Baviskar, Sinha, and Philip 2006:199). An estimated 35,000-50,000 workers were rendered jobless because of this Court-enforced relocation, but were not even heard by the Court until after the closure of the factories (DJAM 1997:22). ${ }^{17}$ A new federation of trade unions and other human rights organizations was formed in December 1996 as a response to the Supreme Court's orders, called Delhi Janwadi Adhikar 
Manch (DJAM-Delhi Socialist Rights Forum, [Nigam 2001]). The Manch tried to intervene in Court, as Amita Baviskar records,

three trade unions affiliated with the Manch approached the bench separately through their lawyers, asking to be heard in the air pollution case. The judges brushed them aside, merely remarking that the Court would protect workers' interests and did not need the intercession of the unions. This verbal assurance was not recorded as a part of Court proceedings (Baviskar et. al 2006:199). ${ }^{18}$

Later again,

when the Manch approached the Supreme Court and pointed out that the judges' orders were being violated, the Court suggested that they take their complaints to the labor commissioner, an official whose previous inaction had already demonstrated his total lack of interest in protecting workers' rights (Bhuwania 2014:200).

The closure suited many of the industries. The bigger ones were in any case keen to shut down or relocate, but Indian labor laws made the closure of an industrial establishment almost impossible. The Court's intervention gave them a timely opportunity. Not only that, this order provided them a real bonanza as they were free to dispose of at least 32 percent of the industrial land as commercial real estate-land that had been earlier given to them by the government at heavily subsidized rates. The Court was not unaware of this as it noted, "In view of the huge increase of prices of land in Delhi the reuse of the vacant land is bound to bring a lot of money which can meet the cost of relocation." 19 On the other hand, it was estimated that the total number of people directly affected by loss of employment (workers and their families) as a result of these orders exceeded 2,500,000 (Baviskar et al. 2006:200).

Within three months of the July 1996 order, the Court also ordered in the same case the relocation or closure of another 513 factories, 46 hot mix plants, 21 arc/induction furnaces and 243 brick kilns, all of which were to be closed down or moved by 1997. This spate of 1996-97 orders was only the first of many major developments in this case that completely reorganized the city. Already, even at that early stage, it was perceived as signaling a new trend. As Baviskar noted,

The partnership of environmentalists MC Mehta and Kuldip Singh, advocate and judge, which resulted in directives that affected the lives and livelihoods of hundreds of thousands of workers and their families, people who had no representation in Court, exemplifies the new efficient dispensation of justice in the "public interest" that middle-class people acclaim (Baviskar et al. 2006:211).

The case continued, though the dramatis personae changed. By the late 1990s, an amicus curiae was appointed in this case-senior advocate Ranjit Kumar-as was the general trend in PIL cases. The public interest petitioner MC Mehta now participated only intermittently, if at all, and henceforth Kumar was to play a key role in the future directions that the case took.

In 2000 came the next major development in the de-industrializing trajectory of this case. This time, the scale was even bigger as the order was to close/relocate all "nonconforming" industrial units, i.e. factories located in areas designated as "residential" in the Delhi Master Plan, the attempt being to strictly enforce Delhi's zoning laws. ${ }^{20}$ The stage was set in 1996 itself, when the Court asked the Delhi Pollution Control Committee (DPCC) for information on the number of polluting and non-polluting units running in non-conforming areas. The resulting survey put the figure of industries in Delhi at 126,218 units, with 97,411 of them being non-conforming (Ahmed 2000). It was decided that only "household industries"-those that did not pollute, employed fewer than five 
workers, used no more than one kilowatt of power, and occupied an area smaller than 30 square meters-would be licensed and allowed to carry on where they were. But only 5 percent of the 51,000 units that applied for these licenses could meet these stringent criteria (Frontline 2000). On April 1, 1996 the Court ordered the rest to be relocated by January 1, 1997. However a fundamental problem arose. There was nowhere to relocate them to, as there were not enough industrial plots as envisaged in the Master Plan. Only after the order was passed in 1996, a government developer called Delhi State Industrial Development Corporation (DSIDC) began to acquire land in Bawana, on the Northern outskirts of the city, where small factories from residential areas could relocate. The Court meanwhile allowed those factory owners who had applied to the DSIDC for alternate plots, temporary licenses to continue operating in their old locations. The Court asked the government to submit quarterly reports about the progress in complying with its orders. In September 1999, the Court heard the case again and fixed the deadline for relocation for December 31, 1999. Eventually by July 2000, 52,000 factories had applied for alternate plot allotments, but not a single factory had been relocated. Because it had still not finished developing the industrial land, in 2000, DSIDC asked the Supreme Court for an extension until March 2004 in order to develop the Bawana industrial properties (Baviskar 2002:202).

24 At this point, the Court lost all patience with the relocation process and on September 12, 2000 , it ordered that "all polluting industries of whatever category operating in residential areas must be asked to shut down." This judicial exasperation with the mendacity and inefficiency of the government would lead to massive devastation in the lives of Delhi's laboring class. As factory owners later complained, "They were bearing the brunt of the punishment that ought to have been meted out to the state for its inaction" (Gill 2009:214).

It was as if the Court had no duty to take care of workers' interests in this massive relocation exercise-that duty was the concern of the government alone. When, after the December 31, 1999 deadline lapsed and the process was nowhere near complete, the Supreme Court issued notice to the government representatives in November 2000 that they would be hauled up for contempt for not implementing the Court's orders, the government panicked and "ordered the immediate closure of all nonconforming industrial units (and not just the polluting ones)" (Gill 2009:203). Almost a hundred thousand factories were thus closed down within a week. Government officials, escorted by heavily armed policemen, went around sealing factory premises, locking their doors, disconnecting electricity and water supply. Riots ensued, with a general strike on November 20, 2000. The accompanying violence led to three workers being shot dead by the police and hundreds injured..$^{21}$ The Court, soon after these incidents, scolded the government for closing not just polluting, but also non-polluting units. However, its new deadline for closing all polluting units was not much later, fixed for January 7, 2001, eventually extended until December 31, 2002 (Gill 2009:203). In the intervening chaos of the 2000-2003 period, thousands of factories closed down, though the Delhi government tried and eventually succeeded in liberalizing the Master Plan norms for factories. The definition of "household" factories was liberalized as well, as 24 areas with about 20,000 factories and a land-use concentration of $70 \%+$ industrial usage re-designated as "industrial," and thus regularized. This issue led to a major political battle between the central and the state governments, as Delhi's land use planning is in the hands of the central government. 
Kaveri Gill has analyzed the impact of this Supreme Court action on a specific "polluting and non-conforming" urban informal industry, that of plastic recycling, which could ironically otherwise be seen as environment-friendly. This community of workers, belonging to a Dalit caste called "Khatik" and working in the plastic scrap trade, had prior to this case been quite successful in exercising their political voice around a caste identity. But the interventions of the PIL Court in this case negated their ability to mobilize politically. The usual democratic channels were bypassed by the Supreme Court. In Gill's analysis,

the elected representatives of the people, in this case Outer Delhi MLAs and others, such as former and present chief ministers from both political parties, were given no avenue to contest the order and influence the course of policy on the basis of

larger trade-offs with poverty and livelihoods in their constituencies (Gill 2009:217).

The Court was thus able to ride roughshod over the negotiations of political society and able to impose its vision of the city via its apotheosis of zoning laws as incorporated in the Master Plan.

In September 2000 the Court had taken the implementation of the order out of the hands of the Delhi Government, instead appointing "an independent nodal agency under the auspices of the Central Government to ensure that the relocation took place within the desired timeframe" (Gill 2009:209). The Central Minister for Urban Development was to head this nodal agency. It was not a co-incidental choice of appointee, as the then incumbent was none other than Jagmohan, the man responsible for the massive Emergency-era social engineering in Delhi. The Court showed its hand here, knowing full well that "Delhi governments lacked the political will to carry out relocation orders, as it would adversely affect the livelihood and business of hundreds of thousands of voters" (Gill 2009:209) and that if there was one person in government who could implement these far-reaching orders, it was Jagmohan. And soon enough, the relocation orders "came to be associated with Jagmohan's office and person" and in the discourse of the displaced, with the Emergency-era dislocations (Gill 2009:209). The Court's actions reminded the factory owners of the Emergency years, specifically, as Gill notes, because:

the Supreme Court refused to hear the lawyer representing the collective body of small-scale traders and manufacturers affected by the relocation order. Various locality- and community-based trade associations had spent a considerable amount of time and effort raising substantial sums of money in order to hire a lawyer willing to defend them, only to have the Supreme Court have him sit down without an adequate hearing (Gill 2009:213).

As with the auto-rickshaws, affected parties were not heard by the PIL Court, before their fate was sealed. Jagmohan was eventually removed from the Urban Development Ministry in 2001 at the behest of his own party leaders from Delhi, when he refused to ratify the change in land-use norms to regularize de facto "industrial areas." He was then made the Tourism Minister, a position in which he wreaked further havoc, acting with unusual alacrity in a Delhi High Court PIL to demolish Delhi's largest slum complex in Yamuna Pushta.

\section{WP 4677/1985 becomes "the sealing case"}

After having successfully deindustrialized the city through this single PIL, Writ Petition (Civil) 4677/1985, the Supreme Court went further down the path of making Delhi a "world-class city" with a judgment on February 16, 2006 in this same case proclaiming 
that all commercial units in residential areas would be closed down. This directive took the zoning logic of the Delhi Master Plan further, with its clear separation of residential and commercial establishments. This PIL 4677/1985, which until 2005 was officially called "RE: Shifting of Industries from Residential Area of Delhi, New Delhi" in its recorded orders, took a new direction after March 17, 2005, when a bench headed by Justice YK Sabharwal, acting at the behest of amicus curiae Ranjit Kumar, decided "to hear and decide the issue of commercialization of residential areas."

This fateful move would make the case even more infamous than it already was-and both this judge and this Amicus lawyer would be identified with this new chapter of this PIL. The Court's intervention would affect hundreds of thousands of commercial establishments in Delhi, as the desired zoning separation existed only on the map. The contradictions between the Master Plan's desired city and the city that in fact existed were so numerous that many even surmised that the majority of shops in Delhi would turn out to be in areas demarcated as non-commercial, and would therefore be guilty of "misuse of property." In fact, the judgment of February 16, 2006 records that the lawyer for MCD had argued that, "since there is a large-scale misuse of residential premises for commercial purposes, it is a physical impossibility to remove the misuser." The Court reacted with anger: "Such a contention is not open to MCD. It is not merely a case of only lack of will to take action, it appears to be a case of predominance of extraneous considerations." The state's role in this process, in the eyes of the Court, was seen as tolerating these illegalities and indeed being complicit in them, partly explained as "corruption" and partly as "vote bank politics," but often narrated as a jumble of the two. Or, as Justice YK Sabharwal wrote in a newspaper article about this case after his retirement, "Judges decide on law and not on populism" (Sabharwal 2007).

The municipal authorities were therefore ordered to seal these commercial properties so that they could no longer be (mis)used. The extreme mismatch between the de jure and de facto situation here has often been explained away in terms of the modernist state's attempt to impose western zoning ideas alien to Indian sensibilities and therefore impractical. But it could, at least partially, also be attributed to the abject failure of the state authorities, in being able to implement their own Master Plan. There were projections with a timeframe in the Master Plan for a certain amount of commercial space to be developed for expected populations by specific dates. The state, repeating its record with the industrial estates, did not end up developing even half the commercial space it was supposed to. The resulting mismatch of supply and demand of commercial land led-not surprisingly-to shops opening in areas demarcated as "non-commercial." The Delhi Development Authority (DDA) was the sole developer, having acquired agricultural land all over the city in the 1950s and 60s and being given the responsibility to develop it. But the DDA completely failed to provide industrial, commercial or indeed residential properties in the measure estimated by its own plan document. Without holding the DDA and its failed monopoly accountable, the Court repeatedly penalized the unplanned construction of industrial, commercial or residential establishments. It went about treating the symptom rather than the cause.

31 Once again, the people who ran commercial establishments and worked in them were going to be penalized in the name of clamping down on illegality, without being heard in the process. The state's fundamental failure in creating the demand for these illegalities by not delivering the commercial space it targeted in the Master Plan, was impatiently glossed over. While the Court ignored this omission, it relied on the same document as 
gospel to insist on strict enforcement of zoning. It thus was wilfully blind to the impossibility of what it was demanding, by harping on illegalities while ignoring the underlying reason behind them. Because the Court had ordered the sealing of commercial establishments in areas not designated as commercial, the case came to be known as "the sealing case." It was under that name that the Supreme Court dominated the newspaper headlines in Delhi in 2006-07.

Once the Court had decided to start the crackdown on "misusers," it asked the MCD about the process it wanted to adopt to go about this mammoth operation. The MCD suggested a four-part plan: it was to start first with a survey of misuse which would take six months, followed by notices issued to the misusers identified; then an opportunity of being heard would be granted and finally properties would be sealed, with a focus on the blatant and obvious cases of large-scale misuse. But the Court had no patience for following such a process. Instead, it wanted a public notice to be issued immediately (within ten days) in major newspapers stating that violators would have 30 days to stop misuse on their own, and file an affidavit saying they would themselves close shop and resume residential use. After 30 days, if misuse did not stop, the MCD would start the process of sealing, starting on major roads. This was the Court's plan of action. What followed however was much more complicated, as for once the Court had taken on a really powerful lobby-the traders and shopkeepers of Delhi. ${ }^{22}$

Initially things seemed to be following the Court's script. The first public notice was issued on February 26, 2006, stating that the first phase of sealing would target those roads with more than 50 percent commercial misuse as well as other major roads above a specified width. On March 24, a little over a month after the Court's initial sealing order of February 16, some traders' associations approached the Court for more time to stop misuse, and the Court directed that the affidavits for voluntarily ceasing misuse would have to be filed within the next four days, by March 28, following which they would be given until June 30. But for those who did not file an affidavit, the sealing action would commence on March 29, 2006. The March 28 deadline for affidavits was extended to April 7, but sealing operations had started by then. 40,800 affidavits were filed in this allotted time, swearing to cease misuse by June 30 and "giving an undertaking to the effect that violation of this would ... subject him/her to offence of perjury and contempt of Court for violation of the order of the Court" (The Hindu 2006). But the large number of shop owners who filed affidavits was still only a fraction of the total commercial establishments affected by the Court orders. For the others, the sealing action had begun, a Court-led campaign cheered on by the drumbeat of the daily newspapers.

Not trusting the municipal bodies' ability and willingness to carry out its orders without constant prodding, on March 24, 2006, the Supreme Court appointed a monitoring committee, "in order to oversee the implementation of the law, namely sealing of offending premises in terms of the letter and spirit of this Court's directions." The Committee was headed by Bhure Lal, the retired bureaucrat who also headed the EPCA, which continued to give reports on vehicular pollution-related issues. The other two members of this Committee were KJ Rao, another retired bureaucrat and Major General (Retired) Som Jhingan. They were allotted office space in Delhi's swanky NGO-cumcultural hub, the India Habitat Centre. By this time, the petitioner advocate MC Mehta in whose name the original case was still continuing, 21 years after he filed it, hardly ever appeared in Court. Instead, the amicus curiae Ranjit Kumar had taken charge. The Court had "directed that all the petitions relating to sealing in Delhi are to be routed through 
the learned Amicus Curiae." ${ }^{23}$ This meant that any petition relating to sealing of any commercial establishment in Delhi had to be dealt with as part of this case and not independently. And the Amicus decided when and how it was heard by the Court. This was of great significance, as soon there were thousands of interlocutory applications (IAs) and Writ Petitions filed by owners of commercial establishments aggrieved by the sealing actions taken pursuant to Court orders. As the Court orders were broad and the sealing was to be done by the Municipal Corporation of Delhi (MCD), supervised by the Monitoring Committee, the question often arose of ascertaining whether in a specific case of an establishment being sealed, it was violating the Master Plan or not. Also, getting temporary relief for removal of supplies already stocked up in the shops, became a repeated cause of affected parties approaching the Court. In such a situation, with the number of applications proliferating in the same case, it became cluttered and extremely difficult to manage. The amicus, who had a monopoly on deciding which applications would be heard by the Court and when, occupied an increasingly powerful position.

This 1985 PIL writ petition number 4677/1985 was what I call an "omnibus PIL." This meant that the case had become a juggernaut which dealt with, for example, all aspects relating to "misuse of properties" at a city-wide level, with the Master Plan being the reference point in deciding the scale of the problem and its geography, and all other individual cases filed pertaining to this issue would be deemed to be a part of the omnibus case. Since there were obviously a very large number of properties affected, only a relatively small number of them could be sealed every day. The newspapers approvingly reported this sealing process on a daily basis, with comments by the members of the Monitoring Committee as they accompanied the MCD sealing squad. The monitoring committee acquired a reputation for their zeal in removing the "illegalities" from the city, and their activities were vociferously backed by the media and the Resident Welfare Associations (RWAs)-organizations of middle-class residents of gated colonies that proliferated in Delhi in the 2000s.

The massive outcry from the traders and shopkeepers that followed the sealing actions under the orders of the Court also got public attention, but it was seen by the newspapers and the Courts as colored by "political society" and its illegalities. And "political society" did indeed intervene, this time speedily unlike at the time of the relocation of industries. While the state had till now mostly allowed the Court to shape the city as per its wishes, with the sealing matter, the political stakes became too high. The shopkeepers and traders of Delhi had always been a powerful constituency and both the leading parties were quite agitated about sealing, unlike the slum demolitions issue.

On March 28, 2006, the day before sealing was to start, a notification was issued by the Delhi Development Authority (DDA) modifying the Master Plan insofar as the chapter on mixed use was concerned. The aim was to take a liberal view regarding mixed land use, i.e. the provision of non-residential activity in residential premises (see Press Information Bureau 2006). The attempt was to give relief to small shopkeepers affected by the Supreme Court directive, allowing some commercial activities to run in residential areas. The new policy to legalize commercial activities on the ground floor of residential premises would be applicable on 118 roads in the capital. This was however still too minuscule a relief-and two days after the sealing started; the traders went on a 48-hour strike amid a flurry of political activity. On April 10, Delhi traders met the President of India, APJ Abdul Kalam and sought his intervention, arguing that the business community was neither a petitioner nor respondent in the PIL under which action was being taken 
against them. Initially, the government tried to get a six-month reprieve from the Court to "complete the exercise of identifying mixed use roads and streets in residential areas within six months in a systematic and organized manner as per provisions of the Delhi Master Plan." But this cut no ice with the Court and it criticized the government for its "policy of appeasement." The Bench of Chief Justice YK Sabharwal and Justice CK Thakker observed on April 28: "Appeasement causes confusion. We extended the time [for sealing] but meanwhile it [Centre] came out with a notification. By doing so what message you [Centre] want to convey to the law abiding citizen... It is a deliberate failure because of extraneous considerations at the cost of the citizen and the message is the law abiding citizen suffers." The apex Court also observed that it was because of the nexus between government officials, law enforcing agencies and businessmen that there was unauthorized commercial use of the residential areas (Singh 2006).

Amidst the Court's intransigence and bipartisan political support, the government finally introduced a new law in Parliament called the Delhi Laws (Special Provisions) Act, 2006. This proposed a one-year moratorium from punitive action against unauthorized development in the capital and provided for status quo as of January 1, 2006 on unauthorized development in respect of mixed land use, construction beyond sanctioned plans and encroachment by slum dwellers, hawkers and street vendors in the city. On May 12, 2006, the Delhi Laws (Special Provision) Bill, 2006 was passed by the Lower House; the Upper House passed it three days later, and on receipt of assent of the President on May 19, 2006, it was notified the same day-an unusually fast pace for a Central legislation. The very next day, the Government of India issued a Notification placing a moratorium for a period of one year with respect to all notices issued by local authorities regarding categories of unauthorized development. With the Act and this notice, the government tried to relieve those who had given an undertaking to the Court, and also issued directions for removal of seals that had been placed on the premises until then. As a result, the municipal authorities suspended their sealing drive. By the time the Notification was issued, around 15,000 commercial establishments functioning in residential areas had already been sealed, out of which 6,000 were de-sealed after the Court received affidavits from the owners.

The constitutionality of this new statute was challenged immediately and came up before the same "sealing" bench of the Supreme Court. Initially, the Court just expressed outrage in oral remarks calling this new law "wholly invalid and void," and declared that "this is pure and simple legislature over-ruling this Court." The Court speculated that the statute might be unconstitutional, but refused to stay its operation until the constitutionality question had been adjudicated. On August 10, 2006, however, while the Court still made oral statements from the bench that "though prima facie the Act is an 'invalid' statute, we are not inclined to completely stay the legislation" (Singh), it insisted on suspending the notification that had been passed a day after the Act was passed, as it was seen as expressly trying to undo and overrule the actions that the Court had already taken.

40 The premise was that even if the sealing of new areas covered under the moratorium was now barred, the government could not undo actions with respect to the specific establishments against which the Court had already taken action, either in terms of affidavits filed undertaking to stop misuse by June 30 or in cases of establishments already sealed. The Court therefore ordered the Municipal authorities to re-seal some 5,000 shops, which had been first sealed by the Court and then unsealed by the 
government. The Court also ordered the sealing of the 40,800 shops that had given affidavits to stop commercial activities on their premises after September 15 (extended from the earlier date of June 30). Two categories had emerged-those who had given affidavits and those who had not.

The government was at first wrong-footed and had to undo its earlier notification with a fresh notice. But amidst the resumption of the sealing, after three months and a fresh crisis, the Delhi Government finally amended the Master Plan in September, declaring large areas-that already had massive commercial presence but were still designated "residential"-"commercial." The amended Plan also declared that some residential colonies could have commercial establishments in their midst. Colonies, as residential neighborhoods in Delhi are called, were categorized from A to $G$ by size of residential plots and density of population (both being indicators of "posh'ness," an English word that has successfully been adopted into Delhi Hindi). Except for "A" and "B" areas, where zoning was to be strictly enforced, with minor exceptions allowed only if the local RWAs agreed, the other categories were granted a reprieve. The government also issued two notifications in September 2006, clearing 2,183 roads for mixed land use, commercial stretches and pedestrian shopping streets in the C, D, E, F, G and $\mathrm{H}$ categories of colonies across the capital. As the sealing continued, a "Bandh" against the sealing campaign called by the Confederation of All India Traders on September 20, 2006 led to violence and five people died by police weapons fire in Seelampur, one of the poorest parts of East Delhi (Sethi 2006). These actions by the government as well as the protests were, of course, immediately condemned by the media, the RWAs and the Court as unseemly vote-bank politics.

With the conflict heating up, on September 29, 2006, the Court criticized the government for these notifications, calling them "ad hoc measures" and orally observed that "the last minute notifications are causing utter confusion and chaos to the citizens... An impression is given as if judiciary is on one side and government on the other side." It continued to insist that at least the 40,000-odd people who had already filed affidavits undertaking to stop misuse would still have to comply with the Court's order or have their shops sealed to protect "the dignity and authority of the Court." The Court allowed them until October 31, 2006 on account of the festival of Diwali. With regard to those who had been saved by the new September notifications, the Court required fresh undertakings to be filed by all before the Monitoring Committee by November 10, 2006 (later extended to January 31, 2007) that misuse would be stopped as per the Court directions if the law was invalidated and/or the notifications quashed. It also declared that sealing would continue vis-à-vis others not covered by the notifications. The Court restrained the government from issuing any other notification for conversion of residential use into commercial use except with the leave of the Court.

With the October 31 deadline approaching and another bandh call given by the traders at the perceived discrimination against the 40,000 traders who had given undertakings, the MCD and the Government again approached the Court. This time they were armed with a survey which said that 25,000 out of these 40,000 odd would be covered by the September mixed-land use notifications. The Court finally recognized the anomaly in insisting on action against the people who had filed affidavits in time, while others who had not filed would get away, and temporarily barred action against them. But after the experience of these shops who had filed affidavits, the others covered by the new notifications who were also now required to file fresh undertakings that they would be subject to the 
Court's final decision on the legality of the notifications by January 312007 , hesitated to file any affidavits because they did not want to be in a similar boat in the future. As sealing could now theoretically resume against all of them, the government deployed its final weapon on February 7, 2007. It notified a New Master Plan for Delhi, which incorporated the recent mixed-use notifications and relaxed many of the zoning norms.

The new plan-MPD 2021-was declared an "Anti-Plan plan" by the newspapers and was immediately challenged as invalid in the Supreme Court by the RWAs. The Court again reacted in a similarly to how it had to the other amendments and declared it would examine the constitutionality of the Plan. It also made actions taken as per the new Plan norms subject to the Court's final decision as to its constitutionality. For instance, for the first time, the Plan allowed a third floor to be constructed in a residential building. Initially the Court barred the MCD from giving any permission for the construction of a third floor in residential areas under this provision, but a year later (by an order in March, 2008), the Court allowed it, subject to an undertaking provided by the home owners that they would abide by its final decision on the validity of MPD-2021. An MCD official explained the standard practice that had evolved on this issue after this order: "The Court had said neither the owner nor the person to whom the property would be sold or transferred could claim equity, if the verdict goes against them. We just take an affidavit from the owner stating this." The MCD had already sanctioned almost 25,000 building plans for the third floor by 2011 (Chitalangia 2011). By 2013, this number was estimated to be in the hundreds of thousands.

The writ petition challenging the 2007 Master Plan that arose in this case and was heard along with it, is still pending in Court, and hundreds of thousands of people own and/or live in third-floor residential units throughout the city. But permission to construct this additional floor is given subject to the Court decision and if the Court decides against the New Master Plan norms, these third-floor units would be declared illegal and subject to demolition-a kind of Damocles' sword hanging over people in Delhi due to this case. Meanwhile, the drama of sealing and de-sealing continued off and on even after the MPD-2021 came into force, though with relatively fewer protagonists and lower stakes. After 2009, in particular since the retirement of Justice Arijit Pasayat, who headed this bench after Justice Sabharwal's retirement, hardly any effective hearing took place in this case (Sinha 2013). It had become impossibly unwieldy with hundreds of IAs pending, mostly for the de-sealing of specific previously-sealed premises. For a bench hearing this case for the first time, it was a herculean task to get a handle on the sheer bulk of the files in this case. The cause list of this case alone, listing all the pending matters, would itself run into the dozens of pages. By 2013, as many as 900 IAs connected to this case were still pending. Also pending were the writ petitions challenging the constitutionality of the provisions of the Master Plan 2021, the Delhi Laws (Special Provisions) Act, which had been renewed every year and the DDA notifications allowing mixed land use. The Court had had enough of it by then, and on April 30,2013, the sealing case was divided into two parts and remanded to the lower judiciary. The IAs dealing with factual questions requesting de-sealing were sent to the appellate tribunals of the respective Municipal Authorities in Delhi, and the writ petitions dealing with the more legal questions were referred to the Delhi High Court. The Court had belatedly realized its own limitations in dealing with issues of such complexity and amplitude. Meanwhile, the Delhi Laws (Special Provisions) continues to be extended periodically and was still in force in 2015. 


\section{Conclusion}

46 of Chief Justice YK Sabharwal, who had presided over the sealing matter from the beginning. In fact, he had initiated this matter by his order in 2005 and moved the focus decisively from relocation of "non-conforming industries" to commercial "misuse" of residential properties. On his retirement he confessed that the "sealing case" in the Capital was the most difficult one of his career. He said that he earned the wrath of his friends and relatives on the issue: "My friends and relatives even stopped talking to me. Yesterday one of my relatives [affected by the sealing order] told me sarcastically that I am a big man. I told him I cannot solve individual problems. The problem is because of corruption in the system and flaws in the Master Plan" (The Hindu 2007). Perhaps the uniqueness of the sealing case in Delhi's long history of PIL is not only the amazing alacrity and avidity with which the Government and MCD fought the long-drawn out chess battle with the Court, with one move following another, but also that the potential losers in this case could include the "friends and relatives" of a Supreme Court judge, not something that could be said of the thousands made jobless by the relocation of industries in the same case or indeed, of the slum-dwellers who were made homeless by the PIL Courts' intervention in the 2000s.

As Justice Sabharwal phrased his dilemma: "The issue of sealing was difficult, as on the one hand it was a question of law and on the other it was the sufferings of people." For once, at least, the judge was in a position to encounter (and potentially understand) the "sufferings of people" caused by his PIL orders, unlike in the many other instances of people who lost their livelihoods because of the orders in this very case. The autorickshaw drivers were easy sacrificial lambs for the cause of the environment-unlike, say, diesel car manufacturers. Owners of large factories wanting to close sunset industries and convert them into profitable real estate were given a break by the Court, while the labor working in the same factories paid a heavy price. Smaller factory owners had less space to maneuver in Court but a section of them managed to pull their political weight eventually. But the hundreds of thousands of traders and "mom-and-pop shop" owners of Delhi were an immeasurably more powerful constituency, for political society and eventually, even for the Court. whole year, and allowing the Court at best a pyrrhic victory. It is not a story we encounter very often with PIL, but the exception is of interest precisely for that reason. When can people maneuver around an all-powerful PIL Court, and when can they not?

The most unsavory aspect of the sealing case came to light four months after Justice Sabharwal's retirement-causing what writer Arundhati Roy then called a "scandal in the palace" (Roy 2007). In May 2007 the tabloid Midday published a news item pointing out that just when Justice Sabharwal was kickstarting the "sealing case" by turning the longrunning PIL about relocation of industries into a case about misuse of commercial properties, his sons were entering into partnership with two major mall and commercial complex developers, resulting at the very least in a "conflict of interest" as their father led a judicial campaign that indirectly benefited them. Suddenly, the repressed aspect of the sealing case was out in the open: it was about mall owners versus shopkeepers. Closing down shops would create a demand for mall space. The sealing campaign had 
further limited the availability of commercial space for shops, and as Roy put it, "The better-off amongst those whose shops and offices had been sealed queued up for space in these malls. Prices shot up. The mall business boomed, it was the newest game in town." And ironically, the judge who initiated and presided over the sealing campaign against commercial use of residential property, himself simultaneously allowed his sons to use his private as well as official residence for commercial purposes, that too as their firm's registered office! Meanwhile, instead of starting any inquiry against Justice Sabharwal, the whistleblower journalists of Midday were sentenced to four months' imprisonment for contempt of Court, in a hurriedly decided suo motu case ${ }^{24}$ initiated by the Delhi High Court.

Even if the charges of corruption against Justice Sabharwal are unproven and it was perhaps "a borderline case" (Tehelka 2007), the remarkable fact is that a jurisdiction like PIL enabled a judge to wilfully initiate a roving inquiry into a complex issue like zoning that affected millions. He could then decide on the path to be taken and force its implementation at a citywide level with supervision by his own chosen officials, with his own handpicked lawyer deciding the direction of the case and without necessarily hearing the parties affected by his decisions. In such a system, petty corruption is at the very least an occupational hazard. Ideological predilection leading a judge in such a direction is scarcely less dangerous.

51 Such an ideological slant in favor of corporate capital was clearly enunciated in a judgment made by the Supreme Court around the same time that it was leading the campaign against the toleration of illegalities in "the sealing case." On October 17, 2006, the Court delivered its verdict on one of the most conspicuous cases of elite illegality in Delhi. The cause of the controversy was the construction of a huge complex of three "world-class" shopping malls, intended to be the most exclusive in India. The location of these malls was to be the South Delhi ridge, hitherto designated a forest area, and with a history of acute water scarcity in the residential neighborhoods in the vicinity. A PIL had been filed against the malls by concerned citizens of the area. No environmental clearance had been obtained. An "expert committee" appointed by the Court found blatant illegalities and noted that "the location of large commercial complexes in this area was environmentally unsound." But with substantial construction already completed, the committee recommended "a compromise with de facto situation." The environmentalist petitioners protested against such post-facto regularization, and cited various decisions of the Court where it had "taken serious view of unauthorized construction."

The Court brushed aside all objections, having decided already that it was "satisfied about the bona fides" of the mall developers. What the bench did here was to clearly specify its double standards: "The stand that wherever constructions have been made unauthorizedly demolition is the only option cannot apply to the present cases, more particularly, when they unlike (sic), where some private individuals or private limited companies or firms being allotted to have made contraventions, are corporate bodies and institutions and the question of their having indulged in any malpractices in getting the approval or sanction does not arise." (Emphases mine).

Just 18 days before the above verdict, the Supreme Court had passed the following judgment in 4677/1985 at the height of its exasperation in the sealing case:

The city of Delhi is an example of a classical case, which, for the last number of years, has been a witness of flagrant violations of municipal laws, town planning 
laws and norms, Master Plan and environmental laws. It is borne out from various orders and judgments passed by this Court and the Delhi High Court, whether in a case of shifting of hazardous and polluting industries or providing cleaner fuel (CNG) or encroachment of public land and streets or massive unauthorized construction and misuse of properties. It is a common knowledge that these illegal activities are also one of the main sources of corruption.

Through PIL, the appellate judges of Delhi launched a fierce drive to undo illegality and corruption in the municipal regulation of land use of Delhi, of which WP 4677/1985 is the definitive example. However, some of the most flagrant of such violations were the massive building complexes built clearly in violation of municipal norms-Akshardham Temple and Commonwealth Games Village on the Yamuna River Bed, Sainik Farms-the largest unauthorized colony in Delhi and of course, the Vasant Kunj malls. High profile PILs had been filed against all of these conspicuously illegal developments and these were all heard in the same decade that saw so much judicial action against illegally built structures all over the city. However, in each of these cases of egregious violations of municipal laws, the Court rationalized their existence and refrained from intervening. All of these buildings survive unscathed. The wrath of PIL was clearly a selective one.

\section{BIBLIOGRAPHY}

Agarwal, Ravi. 2010. "Fight for a Forest." Seminar. Retrieved February 6, 2018 (http://www.indiaseminar.com/2010/613/613_ravi_agarwal.htm).

Ahmed, Khanduja Sethi. 2000. "Master Plan for Anarchy.” Down to Earth, December 31. Retrieved February 6, 2018 (http://www.downtoearth.org.in/coverage/master-plan-for-anarchy-19111).

Ahuja, Sangeeta. 1997. People, Law, and Justice: A Casebook of Public-interest Litigation. New Delhi: Orient Longman.

Baviskar, Amita. 2002. "The Politics of the City." Seminar. Retrieved February 6, 2018 (http:// www.india-seminar.com/2002/516/516\%20amita\%20baviskar.htm).

Baviskar, Amita, Subir Sinha, and Kavita Philip. 2006. "Rethinking Indian Environmentalism Industrial Pollution in Delhi and Fisheries in Kerala." Carnegie Council for Ethics in International Affairs. Retrieved February 6, 2018 (http://www.carnegiecouncil.org/education/006/ forging_environmentalism/01/contents/part_1/5284.html).

Baxi, Upendra. 1980. Indian Supreme Court and Politics. Lucknow: Eastern Book Co.

Bell, Ruth Greenspan, Kuldeep Mathur, Urvashi Narain, and David Simpson. 2004. "Clearing the Air: How Delhi Broke the Logjam on Air Quality Reforms." Environment 46(3):22-39.

Bhuwania, Anuj. 2014. "Courting the People: The Rise of Public Interest Litigation in Postemergency India." Comparative Studies of South Asia, Africa and the Middle East 34(2):314-35.

Chatterjee, Partha. 2004. The Politics of the Governed. Delhi: Permanent Black.

Chatterjee, Partha. 2013. Lineages of Political Society: Studies in Postcolonial Democracy. New York: Columbia University Press. 
Chitlangia, Risha. 2011. "Delhi: Future of Third Floors Hangs on SC Ruling.” Economic Times, December 21. Retrieved February 9, 2018 (http:// articles.economictimes.indiatimes.com/2011-12-21/news/30542927_1_third-floor-mpd-mcdofficials).

Chowdhury, Nupur. 2014. "From Judicial Activism to Adventurism: The Godavarman Case in the Supreme Court of India.” Asia Pac. J. Envtl. L. 17:177-89.

Dasgupta, Nandini. 1998. “Tall Blunder." Down to Earth, September 30. Retrieved February 9, 2018 (http://www.downtoearth.org.in/node/22419).

Divan, Shyam. 1995. “Cleaning the Ganga." Economic and Political Weekly, July 1, pp. 1557-58

Divan, Shyam, and Armin Rosencranz. 2011. Environmental Law and Policy in India: Cases, Materials and Statutes. New Delhi, New York: Oxford University Press.

DJAM (Delhi Janwadi Adhikar Manch). 1997. The Order That Felled a City. New Delhi: DJAM.

EPCA. 2010. Report Number 34: "Review of Existing Cap on the Number of Three-wheelers in Delhi and its Implications for Pollution and Congestion." Retrieved February 6, 2018 ( www.indiaenvironmentportal.org.in/files/epca_0.doc).

Faruqui, Danish, and Raghav Sud. N.d. “Auto-rickshaws in Delhi: Murder by Regulation.” Retrieved February 9, 2018

(http://ccsindia.org/ccsindia/policy/live/studies/wp0002.pdf).

Frontline. 2000. "In Defence of Judicial Activism.” Frontline, December 9-22. Retrieved February 6, 2018 (http://www.frontline.in/static/html/fl1725/17250160.htm).

Gill, Kaveri. 2009. Of Poverty and Plastic: Scavenging and Scrap Trading Entrepreneurs in India's Urban Informal Economy. New Delhi: Oxford University Press.

Harding, Simon. 2011. "A Few Questions about a Few Thousand New Auto-rickshaws in Delhi." Kafila.org. Retrieved February 9, 2018 (http://kafila.org/2011/11/20/a-few-questions-about-afew-thousand-new-auto-rickshaws-in-delhi-simon-harding/).

Hidayatullah, Justice M. 1984. "Highways and Bylanes of Justice." 2 Supreme Court Cases (Journal) 1. Jaffrelot, Christophe. 2000. "The Hindu Nationalist Movement in Delhi: From 'Locals' to Refugees -and towards Peripheral Groups?" Pp. 181-204 in Delhi: Urban Space and Human Destinies, edited by V. Dupont, E. Tarlo, and D. Vidal. Delhi: Manohar Publishers and Centre de Sciences Humaines.

Mathur, Kuldeep. 2003. Battling for Clean Environment: Supreme Court, Technocrats and Populist Politics in Delhi. Retrieved February 9, 2018 (http://www.jnu.ac.in/cslg/workingPaper/CSLG\%20WP\% 2003-01\%20Kuldeep\%20Mathur.pdf).

Mehra, Diya. 2012. "Protesting Publics in Indian Cities: The 2006 Sealing Drive and Delhi's Traders." Economic and Political Weekly 47(30):79-88.

Mehta, Pratap Bhanu. 2007. “The Rise of Judicial Sovereignty.” Journal of Democracy 18(2):70-83.

Mohan, Dinesh, and Dunu Roy. 2003. "Operating on Three Wheels: Auto-rickshaw Drivers of Delhi." Economic and Political Weekly 38(3):177-80

Nigam, Aditya. 1997. "Whose Delhi Is It Anyway? The Struggle against a Black Judgment." Revolutionary Democracy III(1).

Nigam, Aditya. 2001. "Dislocating Delhi: A City in the 1990s." Sarai Reader 01: The Public Domain. Nyaya Bhoomi v. Transport Department. 2011. Delhi. Retrieved February 6, 2018 (http:// nyayabhoomi.org/autorickshaw-service/auto-finance-mafia). 
Press Information Bureau, Government of India. 2006. "Mixed Land Use: Notification Issued." Ministry of Housing and Urban Affairs. Retrieved February 6, 2018 (http://pib.nic.in/newsite/ erelease.aspx?relid=16908).

Rheinstein, Max, ed. 1954. Max Weber on Law in Economy and Society. New York: Simon and Schuster.

Rosencranz, Armin and Michael Jackson. 2003. "The Delhi Pollution Case: The Supreme Court of India and the Limits of Judicial Power." Columbia Journal of Environmental Law 28:223-54.

Roy, Arundhati. 2007. "Scandal in the Palace." Outlook, October 1. Retrieved February 9, 2018 ( http://www.outlookindia.com/article.aspx?235689).

Rudolph, Lloyd, and Susanne. 2008. "Judicial Review and Parliamentary Sovereignty." Pp. 182201 in The Realm of Institutions, edited by L. and S. Rudolph. New Delhi: Oxford University Press.

Sabharwal, Y. K. 2007. “A Former Chief Justice of India Defends his Honour.” Times of India, September 2.

Sethi Aman. 2006. "Uneasy reprieve.” Frontline 23(20). Retrieved February 6, 2018 (http:// www.flonnet.com/fl2320/stories/20061020002903400.htm).

Sharan, Awadhendra. 2005. “'New’ Delhi: Fashioning an Urban Environment through Science and Law." Sarai Reader 5: Bare Acts.

Sharan, Awadhendra. 2014. In the City, Out of Place: Nuisance, Pollution, and Dwelling in Delhi, C. 18502000. New Delhi: Oxford University Press.

Singh, Sandeep. 2006. "Delhi: Demolitions and Sealings." Outlook, September 20. Retrieved February 9, 2018 (http://www.outlookindia.com/article.aspx?232582).

Sinha, Bhadra. 2013. "After 7 yrs, SC wants HC to Hear Sealing Cases." Hindustan Times, April 12. Retrieved February 6, 2018 (http://www.hindustantimes.com/newdelhi/after-7-yrs-sc-wants-hcto-hear-sealing-cases/article1-1042964.aspx).

Tehelka. 2007. "Instead of Helping Shopkeepers, He Made His Sons Rich.” Tehelka, August 18. Retrieved February 9, 2018 (http://archive.tehelka.com/story_main33.asp? filename=Ne180807Instead.asp).

The Hindu. 2006. "Delhi Corporation Moves Apex Court." The Hindu, November 1. Retrieved February 9, 2018 (http://www.hindu.com/thehindu/thscrip/print.pl? file $=2006110115971400$. htm $\&$ date $=2006 / 11 / 01 / \&$ prd $=$ th $\&$ ).

The Hindu. 2007. "Delhi Sealing Case Most Difficult of My Career." The Hindu, January 14. Retrieved February 6, 2018 (http://www.hindu.com/2007/01/14/stories/2007011416400100.htm). Trust, Aman. N.d. "On the Road to Nowhere? Autorickshaws in Delhi: The System, Problems and Recommendations." New Delhi: AMAN Public Charitable Trust. Retrieved February 9, 2018 ( http://www.amanpanchayat.org/Files/Reports/Auto\%C2\%AD-rickshaws_Delhi.pdf).

Verma, Gita Dewan. 2002. Slumming India: A Chronicle of Slums and Their Saviours. New Delhi: Penguin Books India.

\section{NOTES}

1. Writ Petition (Civil) No. $13381 / 1984$

2. Writ Petition (Civil) No. 3727/1985 
3. Writ Petition (Civil) No. 13029/1985

4. For an extended discussion of the ideological roots of this new informalism of the postemergency period, see Bhuwania (2014).

5. The members of this committee were DK Biswas, Chairman of the Central Pollution Control Board, Anil Aggarwal of the Centre for Science and Environment, Shri Jagdish Khattar of Maruti Udyog Limited, and Ms. Kiran Dhingra, Transport Commissioner of Delhi.

6. See the Supreme Court judgment at http://www.indiaenvironmentportal.org.in/files/file/28\% 20July\%201998.pdf

7. On March 26, 2001, the Supreme Court extended this deadline to September 30, 2001, provided auto-rickshaw-owners "who have placed firm orders for new CNG vehicles or for conversion to CNG mode" "give details on affidavits by $31^{\text {st }}$ March, 2001 about their existing vehicles, as also details of the orders placed by them for new CNG vehicles or for conversion to CNG mode." The difficulties in this process of getting an official document to prove that such an order has been placed is discussed in Faruqui and Raghav Sud (N.d.). This caused a situation where tens of thousands of auto-rickshaw-owners had to file the requisite affidavits in the Supreme Court in five days' time, leading to an unprecedented situation in the Supreme Court registry. As a result of this melee and the confusion caused by the conversion process, the number of auto-rickshaw permits in Delhi declined from 83,000 to 50,000 in 2002.

8. Paragraph 9 of the Order of 16.12.1997.

9. Order dated September 3, 2009. The EPCA accordingly submitted its Report Number 34 on "Review of Existing Cap on the Number of Three-wheelers in Delhi and its Implications for Pollution and Congestion" in January 2010. The Court finally granted permission for an increase on November 18, 2011.

10. The application on behalf of the auto-rickshaw unions was first moved in this case to the Supreme Court in 2009.

11. In 2011, an estimated $90 \%$ of TSRs were owned by financiers as opposed to drivers, according to the Special Leave Petition (Civil) 22870-22871 of 2011 in Nyaya Bhoomi v. Transport Department (2011).On the other hand, in 2001, an estimated 65 percent were driven by their owners. See Mohan and Roy (2003).

12. See Mehta (2007). For older versions of this theory of Modus Vivendi, see Rudolph and Rudolph (1981). The classic account remains Baxi (1980).

13. WP(C)202/1995. For a discussion of the role of the amicus curiae in "the forest case," see Chowdhury (2014:177). Chowdhury provides instances to "illustrate how the amicus curiae in this case was able to repeatedly influence the Court's thinking" (2014:185).

14. For a discussion of the writ petition filed in this case, see Sharan (2014:200)

15. The most important of the many applications filed in this case turned out to be IA No. 22/1995, under which the orders in the next three phases of this case would nominally be passed.

16. AIR 1996 SC 2231.

17. For the higher figure and contextualizing discussion, see Nigam (2001).

18. For an uncannily similar move to exclude affected groups from being heard in "the forest case," see Bhuwania (2014:332).

19. (1996) 4 SCC 750

20. While the July 1996 order about the 168 industries was about those falling under the highly polluting " $\mathrm{H}$ " category, (which needed to be relocated out of Delhi in a neighbouring district), industries belonging to Categories B, C, D, E, F and G, located in "non-conforming" areas, as classified by the Master Plan, were to be moved to designated industrial areas. See Gill (2009:225). 21. I remember being forced to walk to my workplace at the time, a distance of more than ten kilometers, witnessing the scenes of complete breakdown, the like of which I have never seen before or after in my long stay in Delhi. 
22. For an insightful account of the mobilization of "traders" against the sealing case, see Mehra (2012).

23. This had become standard practice in PILs by then. See Bhuwania (2014:331-33).

24. Or, as it is usually called in India, "Court on its own motion."

\section{ABSTRACTS}

In the last three decades, Delhi, just like many other cities globally, has seen massive changes in its political economy, with a move from industry to services. What marks Delhi's dislocations as distinct however is their source and their basis-they are based not on administrative or municipal policy or executive directions, but on judicial directions in cases of Public Interest Litigation (PIL) concerning pollution in the city. The spectacular efficacy of PIL in carrying out such a role, I will argue in this paper, can be explained not only by the external ideological trends prevailing during this time period, but also by the peculiar nature of PIL itself as a fundamentally unstable and endlessly malleable jurisdiction.

\section{INDEX}

Keywords: judiciary, populism, environment, city, zoning, pollution

\section{AUTHOR}

\section{ANUJ BHUWANIA}

Associate Professor in the School of Law, Governance and Citizenship at Ambedkar University, Delhi 